$\begin{array}{ll}\text { Research Square } & \text { Preprints are preliminary reports that have not undergone peer review. } \\ \text { They should not be considered conclusive, used to inform clinical practice, } \\ \text { or referenced by the media as validated information. }\end{array}$

\title{
Evaluation of clinical outcomes of antibiotic treatment and appendectomy for appendicitis: Systematic review and meta-analysis of randomized controlled
} trials

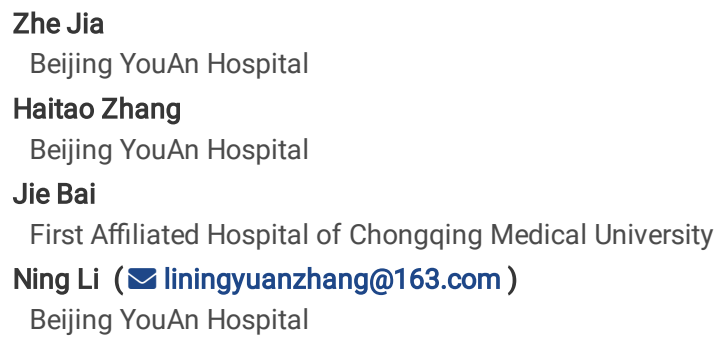




\section{Abstract \\ Background and aims:}

Studies have exhibited the superiority of appendectomy to antibiotics in acute appendicitis (AA) treatment for the overall effective rate and relapse. However, evidence to support the efficacy of appendectomy is lacking because limited randomized controlled trials (RCTs) have been conducted. Thus, the present study attempted to compare the two treatment methods through the meta-analysis of RCTs.

\section{Methods}

Databases such as PubMed, Cochrane Library, Medline, Embase, and Web of Knowledge were searched. RCTs comparing conservative therapy and surgical treatment for AA and published in any language between January 1, 1990, and December 31, 2020 were included in the study. The primary outcomes were 1year efficiency and incidences of complications, whereas the secondary outcomes were length of stay and sick leave duration. The odds ratios (OR) and mean differences (MD) were combined, and the fixed-and random-effects models were calculated with $95 \%$ confidence intervals (Cls).

\section{Results}

The present study was conducted based on 12 studies involving 4195 patients and comparing appendectomy with antibiotic treatment. Of the total, 2135 patients had underwent appendectomy and 2060 were treated with antibiotics. The 1-year OR after antibiotic therapy and appendectomy was 0.03 ( $95 \% \mathrm{Cl}$ : $0.01-0.06)$. The MD for the two groups for length of stay was 0.38 ( $95 \% \mathrm{Cl}: 0.16-0.61)$. Appendectomy exhibited a significantly higher treatment efficiency at 1 year and shorter hospital stay than antibiotic treatment. However, antibiotic treatment exhibited lower incidences of treatment-related complications (RR: $0.52,95 \% \mathrm{Cl}: 0.37-0.74 ; \mathrm{P}=0.0002)$ and sick leave duration $(\mathrm{P}<0.05)$ than appendectomy.

\section{Conclusions}

Antibiotics are not inferior to appendectomy for the treatment of uncomplicated appendicitis. However, patients with an appendicolith exhibited higher recurrence risk after conservative treatment, and surgery is a better option for such patients.

\section{Introduction}

Acute appendicitis (AA) is the most common surgical emergency, and approximately $7 \%$ of the population may be affected from this disease in their lifetime. ${ }^{1}$ Appendectomy has been the gold standard treatment for AA. However, conservative treatment, especially antibiotic treatment, has been considered an alternative therapy. ${ }^{2}$ Although a few randomized clinical trials (RCTs) have reported the effectiveness and feasibility of antibiotics in AA treatment among adults, the small sample size of these studies and questions about applicability to the general population limit the use of this treatment. ${ }^{3}$ In most countries, including the United States and China, more than $90 \%$ of the patients with AA undergo appendectomy. ${ }^{4}$ However, with the global epidemic of new coronaviruses, the global health system and professional community suggest reconsidering the role of antibiotics in appendicitis treatment. ${ }^{5}$

Fitz et al. described the relationship between appendicitis and pelvic abscess in $1886 .{ }^{6}$ Prior to antibiotic use in the treatment, appendectomy has saved several lives by reducing uncontrollable abdominal infections. However, numerous patients treated through appendectomy presented with mild postoperative complications, which affected the quality of their life. Simultaneously, the function of the appendix and the biological effect of its resection remain unclear.

In 1930, Bailey et al. ${ }^{7}$ described the conservative treatment of appendicitis, which included rest, fasting, and delayed selective appendectomy. Coldrey reported 471 cases of AA treated with antibiotics in 1956, with a mortality rate of $0.2 \%$ and a relapse rate of $14.4 \%{ }^{2}$ An RCT by Eriksson in 1995 reported the comparable efficacy of antibiotics and appendectomy in AA treatment. ${ }^{2}$ These studies challenge the first-line treatment of AA through appendectomy. However, complications such as the long-term recurrence risk of antibiotic therapy are unknown. ${ }^{8}$

A few RCTs have compared the reliability and effectiveness of antibiotics and appendectomy in clinical settings; however, the results of these trials have been contradictory. The conclusions of other meta-analyses are also controversial. ${ }^{9,} 10$ Therefore, the present meta-analysis of all relevant RCTs attempted to compare the long-term efficacy of antibiotics and appendectomy in AA treatment. The main purpose of this meta-analysis was to explore whether the RCTs conducted in recent years support or refute the results of previous studies. ${ }^{11}$

\section{Methods}

\section{Reference retrieval strategy and inclusion criteria}

The systematic evaluation and meta-analysis was performed in line with the recommendations of the Preferred Reporting Items for Systematic Reviews and Meta-Analyses (PRISMA) statement, and the study was registered in the PROSPERO (CRD42021266396) database on July 7, 2021 to describe the purpose and methods of our investigation.

The present meta-analysis was performed in 12 RCTs comparing appendectomy and antibiotics in a total of 4195 patients, of which 2135 patients were treated with appendectomy and 2060 patients were treated with antibiotics. RCTs published in any language from January 1, 1995 to December 31,2020 were 
searched manually from Embase, PubMed, Cochrane, Knowledge Network, FDA.gov, and Clinical Trials.gov databases. Keywords and medical subject heading (MeSH) terms used for the search were: "Appendicitis”, "Ruptured Appendicitis”, “Appendicitis Ruptured”, "Perforated Appendicitis”, "Appendicitis”, “Perforated”, "Anti-Bacterial Agents", "Antibiotics", "Appendectomies", "appendectomy", and "Controlled clinical trial”. A total of 360 articles were searched, 21 articles are duplicates, 300 articles are excluded after review of titles and abstracts, 28 articles excluded after reading the full text and finally, 12 studies were included in the meta-analysis (Fig. 1). ${ }^{15-26}$

\section{Research selection and data extraction}

Relevant RCTs conducted in consenting adults aged between 18 and 70 years with a computed tomography (CT) or ultrasound diagnosis of AA and no history of surgery; with follow-up longer than 1 year; and analyzing treatment efficiency, incidence of complications, length of stay, hospitalization expenses, and length of absence were included in the study. Literature reviews; observational and retrospective studies; news reports; sentiment of experts and editors; studies lacking original data; case reports and single-arm studies; studies overlapping research data; those on patients aged < 18 years or $>70$ years; studies on pregnant or lactating patients; those on patients with liver or renal insufficiency; and those on patients with peritonitis or systemic disease were excluded from the study.

The antibiotics and appendectomy treatment strategies were compared. The primary outcomes were 1-year treatment efficiency comprising relapse-free rates and incidence of complications. The secondary outcomes were length of stay, total expenditure during hospitalization, and sick leave duration. Two clinical researchers (JZ and HTZ) systematically read the titles and abstracts of each study and then read the full text of each study to analyze whether it met the inclusion criteria. The data in the selected studies were extracted and analyzed in detail. Disagreements between the two researchers were resolved by the third researcher (NL). Authors of articles not covering patient data were emailed. Data regarding study details (first author, nationality and publication year), basic patient information, number of participants, follow-up, conclusions, and quality features were extracted. The parameters and baseline comparability between the treatment groups were analyzed.

\section{Statistical analysis}

Meta-analysis was performed using RevMan 5.5.1 software. The effect indices of dichotomy variables were odds ratio (OR) and risk ratio (RR). Additionally, the mean difference (MD) and standardized MD (SMD) within the $95 \%$ confidence interval (Cl) of continuous variables were calculated. The random-effects and the fixed-effects models were used to analyze the 'intention-to-treat' of all included research data. ${ }^{12}$ Random-effects models were compared directly when heterogeneity was high. The random-effects model was used to report results if the results of the two models were different. OR $<1$ indicated that results were more likely to occur in the antibiotic group. A P value of $<0.05$ and $95 \% \mathrm{Cl}$ not including 1 were considered statistically significant. The Mantel-Haenszel method was used to merge OR or RR values to obtain results. The heterogeneity was determined by calculating $\mathrm{I}^{2}$ and using the Q statistical test. ${ }^{13}$ Heterogeneity was considered nonsignificant if either the $\mathrm{P}$ value of the $\mathrm{Q}$ statistic test was $>0.10$ or the $\mathrm{I}^{2}$ value was $<50 \%$. ${ }^{31}$ An $\mathrm{I}^{2}<25 \%$ indicated low heterogeneity, whereas $\mathrm{I}^{2}>75 \%$ indicated high heterogeneity.

\section{Sensitivity and subgroup analysis}

Of the total studies, one study was deleted during sensitivity analysis. If the heterogeneity was significantly reduced after exclusion of a study, the study was considered the main source of heterogeneity. Subgroup analysis was performed for uncomplicated population and unselected patients.

\section{Publication bias}

Biases such as publication bias were identified using funnel plots, ${ }^{14}$ wherein symmetry in the plot was used to estimate the risk of bias. All included RCTs were used to generate bias risk graph and summary.

\section{Results}

Table 1 presents the basic characteristics of the included RCTs, whereas summary and chart of bias risk in RCTs are illustrated in Fig. 2. All the studies were classified as having a high risk of bias.

Of the 12 RCTs, 3 from Sweden ${ }^{15-17}, 3$ RCTs were from Finland, ${ }^{21-23} 1$ RCT was from India, ${ }^{18} 1$ RCT was from Turkey, ${ }^{19} 1$ RCT was from Italy, ${ }^{24} 1$ RCT was from Germany, ${ }^{25} 1$ RCT was from France, ${ }^{20}$ and 1 RCT was from USA. ${ }^{24}$ Although all the 12 RCTs compared a new therapy (antibiotic treatment) and a traditional therapy (appendectomy), 5 of these RCTs did not apply randomized double-blind technique.

\section{Success rate, morbidity rate, length of stay, and loss of work}

Appendectomy exhibited a significantly higher 1-year treatment efficiency than antibiotic treatment. Additionally, no heterogeneity was observed (Fig. 3.1). However, the meta-analysis using data obtained from 10 RCTs indicated the superiority of antibiotic therapy to surgery, with mild heterogeneity in the overall treatment morbidity rates (RR: $0.52 ; 95 \% \mathrm{Cl}$ : $0.37-0.74 ; \mathrm{P}<0.001)$ (Fig. 3.2). For the length of stay (9 RCTs) was significantly shorter for the appendectomy group than for the antibiotic treatment group (MD: $0.38 ; 95 \% \mathrm{Cl}: 0.16-0.61 ; \mathrm{P}<0.001$ ). And six of the $12 \mathrm{RCTs}{ }^{16,18,22-25}$ still recommended the use of appendectomy as the first-line treatment of AA. Additionally, the heterogeneity was acceptable (Fig. 3.3). Only five studies reported 5-year loss of work and risk of bias, and the appendectomy group exhibited longer sick leave time than the antibiotic group $(P<0.05)$; however, the heterogeneity between the two treatment groups was high (Fig. 3.4).

\section{Subgroup analysis by the selected population}


The heterogeneity of overall treatment morbidity rates was assessed using a subgroup analysis. For the uncomplicated population ( 534 patients treated with antibiotics and 558 patients treated with appendectomy), the appendectomy group exhibited higher morbidity rates than the antibiotics treatment group (OR: 0.34; $95 \% \mathrm{Cl}: 0.16-0.70 ; \mathrm{P}<0.05)$. However, for the unselected population (779 patients with antibiotics and 980 patients undergoing appendectomy), no significant difference was observed in the antibiotics treatment group (Fig. 4).

\section{Sensitivity analysis and publication bias}

The heterogeneity of the treatment success rate, complication rate, and hospitalization time significantly reduced after exclusion of one study ${ }^{17}$; however, it did not affect the results. No publication bias was detected in either the antibiotic or the appendectomy group. The funnel plots exhibited good symmetry (Fig. 5).

\section{Discussion}

The present meta-analysis indicated a higher treatment success rate and a shorter length of stay in the appendectomy group than those in the antibiotic treatment group. However, the incidences of treatment-related complications and duration of missed work were significantly lower in the antibiotic treatment group than in the appendectomy group. The present study suggested that antibiotics were not inferior to appendectomy for the treatment of AA (especially uncomplicated appendicitis), and long-term quality of life may be higher with the antibiotic treatment.

Since the first report of appendectomy for appendicitis treatment by Mcburney, surgical treatment has become the gold standard for the treatment of AA. ${ }^{27}$ Eriksson et al. ${ }^{15}$ conducted RCTs to report for the first time that antibiotics were equally effective with no postoperative pain in AA treatment. Thus, the safety and effectiveness of the two treatments are controversial. ${ }^{3,9}$

A RCT allows random grouping of subjects for adopting different interventions. It offers advantages of avoiding various biases, balancing confounding factors, and improving the effectiveness of statistical tests. Thus, RCTs are recognized as the gold standard for evaluating an intervention. ${ }^{28}$ The present meta-analysis was conducted using RCTs to ensure that the data obtained are convincing and exhibit minimal deviation.

Several studies have exhibited the superiority of appendectomy for several reasons. ${ }^{16,18,22-25}$ First, the postoperative recurrence rate associated with appendectomy is negligible. Second, appendiceal tumors and extra-appendiceal pathologies may be detected early after the routine pathological examination, which may affect survival of patients after appendectomy. Third, the global popularization of minimally invasive technology has considerably reduced the incidences of incision infection, abdominal adhesion, and postoperative pain; analgesic use; and hospitalization time after laparoscopic appendectomy compared with those after open appendectomy, which have improved the quality of life of patients. ${ }^{29}$ Finally, the application of broad-spectrum antibiotics may cause bacterial resistance or contribute to the emergence of superbacteria such as methicillin-resistant Staphylococcus aureus, multidrug-resistant Streptococcus pneumoniae, and vancomycin-resistant enterococci. ${ }^{30}$ However, appendectomy has numerous limitations. Because most hospitals in developing countries still perform open appendectomy, the postoperative complications cannot be ignored. Simultaneously, the function of the appendix and the influence of its resection on the human body remain unclear. ${ }^{31}$ Additionally, many patients prefer conservative treatment over surgical treatment.

The present meta-analysis exhibited a statistically significant difference in the 1-year treatment efficacy between the two treatments $(P<0.001$; OR $<0.1)$. However, $70 \%$ of the patients with AA in the antibiotic treatment group exhibited no recurrence within 1 year, whereas approximately $60 \%$ patients exhibited no recurrence within 5 years. ${ }^{32}$ Thus, most patients avoided surgical treatment. Nevertheless, the length of hospital stay for the surgical treatment group was shorter than that for the antibiotic treatment group, which may be attributed to the lack of a definite time guideline for the antibiotic treatment. Most clinical centers consider three days as the time point for early treatment, and the length of hospital stay may be greatly reduced in the later treatment stage. In Italy, the use of oral antibiotics in non-surgical treatment was reported to greatly shorten the length of hospital stay. ${ }^{33}$

Antibiotics therapy offers several theoretical advantages over appendectomy. Compared with surgical resection, conservative treatment exhibited lesser incidences of complications, time missed from work, and hospitalization expenses. Additionally, many patients treated conservatively do not require hospitalization. Because these patients can be treated in the emergency or outpatient department, the treatment efficiency can be improved. This efficient treatment of AA may benefit patients, especially in the COVID-19 pandemic. A high therapeutic effect rate and a low recurrence rate were observed particularly in patients with uncomplicated appendicitis with no appendicolith. ${ }^{26}$ Incidences of surgical complications do not increase even if appendectomy is delayed in patients treated with antibiotics. Although CT scan exhibits high specificity and sensitivity in AA diagnosis, several patients with normal appendix are still treated with transitional surgery. A retrospective study conducted in 3236 patients who received non-surgical treatment, with the average follow-up period of 7 \pm 3.9 years, reported a long-term recurrence rate of only $4.4 \% .{ }^{34}$ Salminen et al. ${ }^{32}$ reported the late recurrence rate of uncomplicated AA after antibiotic treatment in the APPAC RCT. The author concluded that the possibility of late recurrence within 5 years among patients with simple AA who initially received antibiotic treatment was $39.1 \%$. This long-term follow-up study supported the feasibility of antibiotic treatment as an alternative to surgery for uncomplicated AA. The results of the present meta-analysis may be particularly relevant during the COVID-19 pandemic. Patients and clinicians should weigh the benefits and risks of each method by considering the individual characteristics, preferences, and environment. ${ }^{35}$

\section{Study limitations}

The present meta-analysis has certain limitations. The major source of heterogeneity detected in the sensitivity analysis was the study by Hansson, ${ }^{17}$ which had a high crossover rate from medical treatment to surgical treatment. The study by Styrud only included male patients, which resulted in a high risk of bias. Additionally, in some RCTs, publication bias or sources of heterogeneity were introduced due to the small sample size and short follow-up time; these factors might have affected the primary results. Furthermore, the antibiotic treatment regimens in all the studies were different. Different antibiotic levels and 
antimicrobial spectrum may affect the results and serve as a source of heterogeneity. Moreover, only the study by GoryFlum conducted a subgroup analysis for the presence of appendicolith and concluded that patients with an appendicolith detected in preoperative CT examination exhibited a high recurrence rate and were at a high risk of undergoing appendectomy. Although this result is crucial, other studies have not analyzed this aspect. The outcome of health status should be described using the EQ-5D questionnaire, ${ }^{36}$ which could not be performed in most of the studies included in this meta-analysis due to the lack of original data. Furthermore, although funnel plot comparisons were used and exhibited no publication bias between conservative treatment and appendectomy, Egger and Begg regression tests could not be used to determine publication bias due to the limitations of RevMan software. Finally, due to the restrictions of natural factors, randomized double-blind trials could not be realized in the included RCTs. Therefore, we hope that more clinical centers can do large-sample randomized double-blind controlled trials in the future, and compare the two treatments of appendicitis, so that the evidence level of our meta-analysis will be higher.

\section{Conclusions}

Antibiotic therapy is not inferior to appendectomy for AA treatment, and it can be used as the first-line treatment especially for patients with uncomplicated appendicitis who refuse to undergo surgery. However, appendectomy may still be recommended for patients with complex appendicitis, especially those with appendicolith. Further long-term follow-up studies are warranted to establish an optimal treatment for AA.

\section{Declarations}

\section{Acknowledgements}

Thank Ms. Shi Huihan for her support for my work and study. And the authors thank the team of TOPEDIT for proofreading this systematic review and metaanalysis.

\section{Conflicts of Interest and Disclosure statement}

The authors report no conflicts of interest, there were no financial disclosures for any author and no funding was provided by a foundation.

\section{References}

1. Addiss DG, Shaffer N, Fowler BS, et al. The epidemiology of appendicitis and appendectomy in the United States. Am J Epidemiol 1990,132:910-25.

2. Coldrey E. Treatment of Acute Appendicitis. Br Med J 1956,2:1458-61.

3. Ehlers AP, Talan DA, Moran GJ, et al. Evidence for an Antibiotics-First Strategy for Uncomplicated Appendicitis in Adults: A Systematic Review and Gap Analysis. J Am Coll Surg 2016,222:309-14.

4. Sceats LA, Trickey AW, Morris AM, et al. Nonoperative Management of Uncomplicated Appendicitis Among Privately Insured Patients. JAMA Surg 2019,154:141-149.

5. Reichert M, Sartelli M, Weigand MA, et al. Impact of the SARS-CoV-2 pandemic on emergency surgery services-a multi-national survey among WSES members. World J Emerg Surg 2020,15:64.

6. Fitz RH. Perforating inflammation of the vermiform appendix, with special reference to its early diagnosis and treatment. 1 . The American Journal of the Medical Sciences (1827-1924) 1886:321.

7. Bailey H. The Ochsner-Sherren (Delayed) Treatment of Acute Appendicitis: Indications and Technique. Br Med J 1930,1:140-3.

8. Andersson MN, Andersson RE. Causes of short-term mortality after appendectomy: a population-based case-controlled study. Ann Surg 2011,254:103-7.

9. Harnoss JC, Zelienka I, Probst P, et al. Antibiotics Versus Surgical Therapy for Uncomplicated Appendicitis: Systematic Review and Meta-analysis of Controlled Trials (PROSPERO 2015: CRD42015016882). Ann Surg 2017,265:889-900.

10. Yang Z, Sun F, Ai S, et al. Meta-analysis of studies comparing conservative treatment with antibiotics and appendectomy for acute appendicitis in the adult. BMC Surg 2019,19:110.

11. Jia Z, Zhang H, Li N. Evaluation of clinical outcomes of radiofrequency ablation and surgical resection for hepatocellular carcinoma conforming to the Milan criteria: A systematic review and meta-analysis of recent randomized controlled trials. J Gastroenterol Hepatol 2021,36:1769-1777.

12. Newell DJ. Intention-to-treat analysis: implications for quantitative and qualitative research. Int J Epidemiol 1992,21:837-41.

13. Higgins JP, Thompson SG. Quantifying heterogeneity in a meta-analysis. Stat Med 2002,21:1539-58.

14. Macaskill P, Walter SD, Irwig L. A comparison of methods to detect publication bias in meta-analysis. Stat Med 2001,20:641-54.

15. Eriksson S, Granstrom L. Randomized controlled trial of appendicectomy versus antibiotic therapy for acute appendicitis. Br J Surg 1995,82:166-9.

16. Styrud J, Eriksson S, Nilsson I, et al. Appendectomy versus antibiotic treatment in acute appendicitis. a prospective multicenter randomized controlled trial. World J Surg 2006,30:1033-7.

17. Hansson J, Korner U, Khorram-Manesh A, et al. Randomized clinical trial of antibiotic therapy versus appendicectomy as primary treatment of acute appendicitis in unselected patients. Br J Surg 2009,96:473-81.

18. Malik AA, Bari SU. Conservative management of acute appendicitis. J Gastrointest Surg 2009,13:966-70.

19. Turhan AN, Kapan S, Kutukcu E, et al. Comparison of operative and non operative management of acute appendicitis. Ulus Travma Acil Cerrahi Derg 2009,15:459-62. 
20. Vons C, Barry C, Maitre S, et al. Amoxicillin plus clavulanic acid versus appendicectomy for treatment of acute uncomplicated appendicitis: an open-label, non-inferiority, randomised controlled trial. The Lancet 2011,377:1573-1579.

21. Paajanen $\mathrm{H}$, Gronroos JM, Rautio T, et al. A prospective randomized controlled multicenter trial comparing antibiotic therapy with appendectomy in the treatment of uncomplicated acute appendicitis (APPAC trial). BMC Surg 2013,13:3.

22. Mentula P, Sammalkorpi H, Leppaniemi A. Laparoscopic Surgery or Conservative Treatment for Appendiceal Abscess in Adults? A Randomized Controlled Trial. Ann Surg 2015,262:237-42.

23. Salminen P, Paajanen H, Rautio T, et al. Antibiotic Therapy vs Appendectomy for Treatment of Uncomplicated Acute Appendicitis: The APPAC Randomized Clinical Trial. JAMA 2015,313:2340-8.

24. Ceresoli M, Pisano M, Allievi N, et al. Never put equipoise in appendix! Final results of ASAA (antibiotics vs. surgery for uncomplicated acute appendicitis in adults) randomized controlled trial. Updates Surg 2019,71:381-387.

25. Prechal D, Post S, Pechlivanidou I, et al. Feasibility, acceptance, safety, and effectiveness of antibiotic therapy as alternative treatment approach to appendectomy in uncomplicated acute appendicitis. Int J Colorectal Dis 2019,34:1839-1847.

26. Collaborative C, Flum DR, Davidson GH, et al. A Randomized Trial Comparing Antibiotics with Appendectomy for Appendicitis. N Engl J Med 2020,383:1907-1919.

27. McBurney C. IV. The Incision Made in the Abdominal Wall in Cases of Appendicitis, with a Description of a New Method of Operating. Ann Surg 1894,20:38-43.

28. Bothwell LE, Podolsky SH. The Emergence of the Randomized, Controlled Trial. N Engl J Med 2016,375:501-4.

29. Minneci PC, Hade EM, Lawrence AE, et al. Association of Nonoperative Management Using Antibiotic Therapy vs Laparoscopic Appendectomy With Treatment Success and Disability Days in Children With Uncomplicated Appendicitis. JAMA 2020,324:581-593.

30. Zhang J, Xu J, Ma H, et al. Designing an Amino-Fullerene Derivative C70-(EDA) 8 to Fight Superbacteria. ACS applied materials \& interfaces 2019,11:14597-14607.

31. Ansaloni L, Catena F, Pinna A. What is the function of the human vermiform appendix? European Surgical Research 2009,43:67.

32. Salminen P, Tuominen R, Paajanen H, et al. Five-Year Follow-up of Antibiotic Therapy for Uncomplicated Acute Appendicitis in the APPAC Randomized Clinical Trial. JAMA 2018,320:1259-1265.

33. Sippola S, Haijanen J, Gronroos J, et al. Effect of Oral Moxifloxacin vs Intravenous Ertapenem Plus Oral Levofloxacin for Treatment of Uncomplicated Acute Appendicitis: The APPAC II Randomized Clinical Trial. JAMA 2021,325:353-362.

34. McCutcheon BA, Chang DC, Marcus LP, et al. Long-term outcomes of patients with nonsurgically managed uncomplicated appendicitis. J Am Coll Surg 2014,218:905-13.

35. Neufeld MY, Bauerle W, Eriksson E, et al. Where did the patients go? Changes in acute appendicitis presentation and severity of illness during the coronavirus disease 2019 pandemic: A retrospective cohort study. Surgery 2021,169:808-815.

36. Koumarelas K, Theodoropoulos GE, Spyropoulos BG, et al. A prospective longitudinal evaluation and affecting factors of health related quality of life after appendectomy. Int J Surg 2014,12:848-57.

\section{Tables}

Table1: Main information of the include studies 


\begin{tabular}{|c|c|c|c|c|c|c|c|c|c|c|}
\hline $\begin{array}{l}\text { Type } \\
\text { of } \\
\text { study }\end{array}$ & Author & Year & Country & Drug Therapy & $\begin{array}{l}\text { Surgical } \\
\text { Treatment }\end{array}$ & $\begin{array}{l}\text { Numeber } \\
\text { of } \\
\text { Patients }\end{array}$ & $\begin{array}{l}\text { Morbidities } \\
\text { rate }\end{array}$ & Conclusion & Remarks & $\begin{array}{l}\text { follow- } \\
\text { up } \\
\text { (month) }\end{array}$ \\
\hline $\mathrm{RCT}$ & $\begin{array}{l}\text { Eriksson } \\
\text { et al. }\end{array}$ & 1995 & Sweden & $\begin{array}{l}\text { Cefotaxime } 2 \\
\text { g IV Bid and } \\
\text { tinidazole } 800 \\
\text { mg Qd for } 2 \\
\text { days, then oral } \\
\text { ofloxacin } 200 \\
\text { mg Bid and } \\
\text { tinidazole } 500 \\
\text { mg Bid for } 8 \\
\text { day }\end{array}$ & $\begin{array}{l}\text { Open } \\
\text { appendectomy }\end{array}$ & $\begin{array}{l}\text { S: } 20+ \\
\text { D:20 } \\
=T: 40\end{array}$ & $\begin{array}{l}\text { unselected } \\
\text { population }\end{array}$ & $\begin{array}{l}\text { Antibiotic } \\
\text { treatment of } \\
\text { acute } \\
\text { appendicitis is } \\
\text { as effective as } \\
\text { surgery, and } \\
\text { patients with } \\
\text { mild pain, less } \\
\text { analgesia } \\
\text { requirements, } \\
\text { but high } \\
\text { recurrence rate. }\end{array}$ & Less case & 17 \\
\hline RCT & $\begin{array}{l}\text { Styrud, J. } \\
\text { et al. }\end{array}$ & 2006 & Sweden & $\begin{array}{l}\text { IV cefotaxime } \\
\text { for } 2 \text { days and } \\
\text { tinidazole } 800 \\
\text { mg daily, } \\
\text { followed by } \\
\text { ofloxacin } 200 \\
\text { mg }\end{array}$ & $\begin{array}{l}\text { Open or } \\
\text { laparoscopic } \\
\text { procedures }\end{array}$ & $\begin{array}{l}\text { S: } 124+ \\
\text { D: } 128 \\
=T: 252\end{array}$ & $\begin{array}{l}\text { uncomplicated } \\
\text { population }\end{array}$ & $\begin{array}{l}\text { Acute } \\
\text { appendicitis can } \\
\text { be treated } \\
\text { successfully } \\
\text { with antibiotics } \\
\text { with a short } \\
\text { hospital stay, } \\
\text { minimal sick } \\
\text { leave, and } \\
\text { limited duration } \\
\text { of pain, but high } \\
\text { recurrence rate, } \\
\text { which should be } \\
\text { compared with } \\
\text { the rate of } \\
\text { complications } \\
\text { after } \\
\text { appendectomy. }\end{array}$ & $\begin{array}{l}\text { Female } \\
\text { patients } \\
\text { included } \\
\text { only }\end{array}$ & 12 \\
\hline RCT & $\begin{array}{l}\text { Hansson } \\
\text { et al. }\end{array}$ & 2009 & Sweden & $\begin{array}{l}\text { IV cefotaxime } \\
1 \mathrm{~g} \text { BID } \\
\text { and } \\
\text { metronidazole } \\
1.5 \mathrm{~g} \\
\text { q24hr for } 1 \\
\text { day, followed } \\
\text { by oral } \\
\text { ciprofloxacin } \\
500 \text { mg BID } \\
\text { and } \\
\text { metronidazole } \\
400 \text { mg TID } \\
\text { for } 10 \text { days }\end{array}$ & $\begin{array}{l}\text { Open or } \\
\text { laparoscopic } \\
\text { approach as } \\
\text { surgeons' } \\
\text { usual } \\
\text { practice }\end{array}$ & $\begin{array}{l}\text { S: } 167+ \\
\text { D:202 } \\
=T: 369\end{array}$ & $\begin{array}{l}\text { unselected } \\
\text { population }\end{array}$ & $\begin{array}{l}\text { Antibiotic } \\
\text { treatment } \\
\text { appears to be a } \\
\text { safe first-line } \\
\text { therapy in } \\
\text { unselected } \\
\text { patients with } \\
\text { acute } \\
\text { appendicitis. }\end{array}$ & $\begin{array}{l}\text { Non-double } \\
\text { blind, } 52.5 \\
\% \text { antibiotic } \\
\text { treatment } \\
\text { group } \\
\text { transferred } \\
\text { to surgery } \\
\text { group }\end{array}$ & 12 \\
\hline $\mathrm{RCT}$ & $\begin{array}{l}\text { Malik et } \\
\text { al. }\end{array}$ & 2009 & India & $\begin{array}{l}\text { IV } \\
\text { ciprofloxacin } \\
500 \text { mg BID } \\
\text { and } \\
\text { metronidazole } \\
500 \text { mg TID } \\
\text { for } 2 \text { days, } \\
\text { followed by } \\
\text { oral } \\
\text { ciprofloxacin } \\
500 \text { mg BID } \\
\text { and tinidazole } \\
600 \text { mg BID } \\
\text { for } 7 \text { days }\end{array}$ & $\begin{array}{l}\text { Approach not } \\
\text { specified }\end{array}$ & $\begin{array}{l}S: 40+ \\
D: 40 \\
=T: 80\end{array}$ & $\begin{array}{l}\text { unselected } \\
\text { population }\end{array}$ & $\begin{array}{l}\text { The patients } \\
\text { managed } \\
\text { conservatively } \\
\text { with antibiotics } \\
\text { alone } \\
\text { experience less } \\
\text { pain and require } \\
\text { less analgesia } \\
\text { but have high } \\
\text { recurrent rate }\end{array}$ & $\begin{array}{l}\text { Non-double } \\
\text { blind, } 52.5 \\
\% \text { antibiotic } \\
\text { treatment } \\
\text { group } \\
\text { transferred } \\
\text { to surgery } \\
\text { group }\end{array}$ & 18.3 \\
\hline RCT & $\begin{array}{l}\text { Turhan et } \\
\text { al. }\end{array}$ & 2009 & Turkey & $\begin{array}{l}\text { IV ampicillin } 1 \\
\text { g QID, } \\
\text { gentamicin } \\
160 \text { mg daily } \\
\text { and } \\
\text { metronidazole } \\
500 \text { mg } \\
\text { TID for } 3 \\
\text { days, followed } \\
\text { by oral } \\
\text { antibiotics for } \\
10 \text { days }\end{array}$ & $\begin{array}{l}\text { Open or } \\
\text { laparoscopic } \\
\text { appendectomy }\end{array}$ & $\begin{array}{l}\text { S: } 183+ \\
\text { D:107 } \\
=T: 290\end{array}$ & $\begin{array}{l}\text { unselected } \\
\text { population }\end{array}$ & $\begin{array}{l}\text { With its high } \\
\text { success rate } \\
\text { and cost } \\
\text { effectiveness, } \\
\text { medical } \\
\text { treatment } \\
\text { seems to be a } \\
\text { good alternative } \\
\text { to the gold } \\
\text { standard } \\
\text { therapy of } \\
\text { surgery in } \\
\text { management of } \\
\text { acute } \\
\text { appendicitis. }\end{array}$ & $\begin{array}{l}\text { multicenter } \\
\text { study }\end{array}$ & 19 \\
\hline RCT & $\begin{array}{l}\text { Vons et } \\
\text { al. }\end{array}$ & 2011 & France & $\begin{array}{l}\text { Amoxicillin } \\
\text { and clavulanic } \\
\text { Acid of } 3 \mathrm{~g} \text { or } \\
4 \mathrm{~g} \text { according } \\
\text { to weight, with } \\
\text { route and } \\
\text { duration } \\
\text { according to }\end{array}$ & $\begin{array}{l}\text { Open or } \\
\text { laparoscopic } \\
\text { approach on } \\
\text { surgeon } \\
\text { preference }\end{array}$ & $\begin{array}{l}\text { S: } 123+ \\
\text { D:120 } \\
=T: 243\end{array}$ & $\begin{array}{l}\text { uncomplicated } \\
\text { population }\end{array}$ & $\begin{array}{l}\text { Amoxicillin plus } \\
\text { clavulanic acid } \\
\text { was not non- } \\
\text { inferior to } \\
\text { emergency } \\
\text { appendicectomy } \\
\text { for treatment of }\end{array}$ & $\begin{array}{l}\text { multicenter } \\
\text { study }\end{array}$ & 12 \\
\hline
\end{tabular}

Page 7/13 
clinical

symptoms

\begin{tabular}{|c|c|c|c|c|}
\hline RCT & $\begin{array}{l}\text { Paajanen } \\
\text { et al. }\end{array}$ & 2013 & Finland & $\begin{array}{l}\text { Ertapenem ( } 1 \\
\text { g per day) for } \\
3 \text { days } \\
\text { continued by } \\
\text { oral } \\
\text { levofloxacin } \\
\text { ( } 500 \mathrm{mg} \text { per } \\
\text { day) plus } \\
\text { metronidazol } \\
\text { ( } 1.5 \mathrm{~g} \text { per day } \\
\text { for } 7 \text { days. }\end{array}$ \\
\hline
\end{tabular}

acute

appendicitis.

$\begin{array}{lll}\text { Open } & \text { S:305+ } & \text { uncomplicated } \\ \text { appendectomy } & \text { D:305 } & \text { population } \\ & =\mathrm{T}: 610 & \\ & & \\ & & \\ & \end{array}$

Approximately

$75-85 \%$ of

patients with

uncomplicated

AA can be

treated with

effective

antibiotic

therapy

avoiding

unnecessary

appendectomies

and the related

operative

morbidity, also

resulting in

major cost

savings.

\begin{tabular}{|c|c|c|c|c|c|c|c|c|c|c|}
\hline $\mathrm{RCT}$ & $\begin{array}{l}\text { Mentula } \\
\text { et al. }\end{array}$ & 2015 & Finland & $\begin{array}{l}\text { IV cefuroxime } \\
1.5 \mathrm{~g} \times 3 \mathrm{per} \\
\text { day }+ \\
\text { metronidazole } \\
500 \mathrm{mg} \times 3 \text { per } \\
\text { day, follow by } \\
\text { oral oral } \\
\text { cephalexin } \\
500 \mathrm{mg} \times 3 \\
\text { per day and } \\
\text { metronidazole } \\
500 \text { mg } \times 3 \\
\text { per day for } 7 \\
\text { days }\end{array}$ & $\begin{array}{l}\text { Laparoscopic } \\
\text { surgery }\end{array}$ & $\begin{array}{l}\text { S: } 30+ \\
\text { D: } 30 \\
=T: 60\end{array}$ & $\begin{array}{l}\text { appendiceal } \\
\text { abscess. }\end{array}$ & $\begin{array}{l}\text { Laparoscopic } \\
\text { surgery in } \\
\text { experienced } \\
\text { hands is safe } \\
\text { and feasible } \\
\text { first-line } \\
\text { treatment for } \\
\text { appendiceal } \\
\text { abscess. }\end{array}$ & $\begin{array}{l}\text { Follow-up } \\
\text { of only } 60 \\
\text { days for } \\
\text { appendiceal } \\
\text { abscess }\end{array}$ & 2 \\
\hline $\mathrm{RCT}$ & $\begin{array}{l}\text { Salminen } \\
\text { et al. }\end{array}$ & 2015 & Finland & $\begin{array}{l}\text { IV ertapenem } \\
1 \mathrm{~g} \text { daily for } 3 \\
\text { days, followed } \\
\text { by oral } \\
\text { levofloxacin } \\
500 \mathrm{mg} \text { daily } \\
\text { and } \\
\text { metronidazole } \\
500 \mathrm{mg} \\
\text { TID for } 7 \text { days }\end{array}$ & $\begin{array}{l}\text { Open or } \\
\text { laparoscopic } \\
\text { procedures }\end{array}$ & $\begin{array}{l}\mathrm{S}: 273+ \\
\mathrm{D}: 257= \\
\mathrm{T}: \\
530\end{array}$ & $\begin{array}{l}\text { uncomplicated } \\
\text { population }\end{array}$ & $\begin{array}{l}\text { Among patients } \\
\text { with CT-proven, } \\
\text { uncomplicated } \\
\text { appendicitis, } \\
\text { antibiotic } \\
\text { treatment did } \\
\text { not meet the } \\
\text { prespecified } \\
\text { criterion for } \\
\text { noninferiority } \\
\text { compared with } \\
\text { appendectomy. }\end{array}$ & - & - \\
\hline RCT & $\begin{array}{l}\text { Ceresoli } \\
\text { et al. }\end{array}$ & 2019 & Italy & $\begin{array}{l}\text { IV } \\
\text { administration } \\
\text { of } 1 \mathrm{~g} \text { of } \\
\text { Ertapenem } \\
\text { once a day for } \\
3 \text { days during } \\
\text { hospitalization } \\
\text { and further } \\
\text { administration } \\
\text { of amoxicillin/ } \\
\text { clavulanate } 1 \\
\mathrm{~g} \text { per os every } \\
8 \mathrm{~h} \text { for } 5 \text { days. }\end{array}$ & $\begin{array}{l}\text { laparoscopic } \\
\text { procedures }\end{array}$ & $\begin{array}{l}\mathrm{S}: 24+ \\
\mathrm{D}: 21=\mathrm{T} \\
45\end{array}$ & $\begin{array}{l}\text { uncomplicated } \\
\text { population }\end{array}$ & $\begin{array}{l}\text { Due to the poor } \\
\text { patient's accrual } \\
\text { rate the study } \\
\text { failed to } \\
\text { demonstrate the } \\
\text { non-inferiority of } \\
\text { conservative } \\
\text { treatment in } \\
\text { uncomplicated } \\
\text { acute } \\
\text { appendicitis. }\end{array}$ & - & 12 \\
\hline $\mathrm{RCT}$ & $\begin{array}{l}\text { Prechal } \\
\text { et al. }\end{array}$ & 2019 & Germany & $\begin{array}{l}\text { IV ceftriaxone } \\
2 \mathrm{~g} 1-0-0 \text { plus } \\
\text { metronidazole } \\
500 \mathrm{mg} 1-0-1 \\
\text { during the } \\
\text { intended } \\
\text { hospital stay } \\
\text { of } 3 \text { days } \\
\text { followed by } 7 \\
\text { days of oral } \\
\text { ciprofloxacin } \\
500 \text { mg } 1-0-1 \\
\text { plus } \\
\text { metronidazole } \\
400 \text { mg } 1-0-1 .\end{array}$ & $\begin{array}{l}\text { laparoscopic } \\
\text { procedures }\end{array}$ & $\begin{array}{l}S: 70+ \\
D: 54=\mathrm{T}: \\
124\end{array}$ & $\begin{array}{l}\text { uncomplicated } \\
\text { population }\end{array}$ & $\begin{array}{l}\text { Appendectomy } \\
\text { remains the } \\
\text { most effective } \\
\text { treatment for } \\
\text { the definitive } \\
\text { cure of acute } \\
\text { appendicitis. } \\
\text { However, } \\
\text { antibiotic } \\
\text { therapy can be a } \\
\text { safe alternative } \\
\text { approach for } \\
\text { selected } \\
\text { patients with } \\
\text { uncomplicated } \\
\text { acute } \\
\text { appendicitis. }\end{array}$ & $\begin{array}{l}\text { Non-double } \\
\text { blind }\end{array}$ & 12 \\
\hline $\mathrm{RCT}$ & $\begin{array}{l}\text { GoryFlum } \\
\text { et al. }\end{array}$ & 2020 & USA & $\begin{array}{l}\text { IV formulation } \\
\text { for at least } \\
24 \mathrm{~h} \text {, follow by } \\
\text { pills, for } 10- \\
\text { day total } \\
\text { course. }\end{array}$ & $\begin{array}{l}\text { Laparoscopic } \\
\text { surgery }\end{array}$ & $\begin{array}{l}S: 776+ \\
\mathrm{D}: 776= \\
\mathrm{T}: \\
1552\end{array}$ & $\begin{array}{l}\text { unselected } \\
\text { population }\end{array}$ & $\begin{array}{l}\text { This } \\
\text { comparative } \\
\text { effectiveness } \\
\text { trial showed } \\
\text { that, for the } \\
\text { treatment of } \\
\text { appendicitis, } \\
\text { antibiotics were }\end{array}$ & - & 3 \\
\hline
\end{tabular}

Page $8 / 13$ 
noninferior to

appendectomy

on the basis of

results of a

standardized

measure of

general health

status, at least

in the short

term.

\section{Figures}

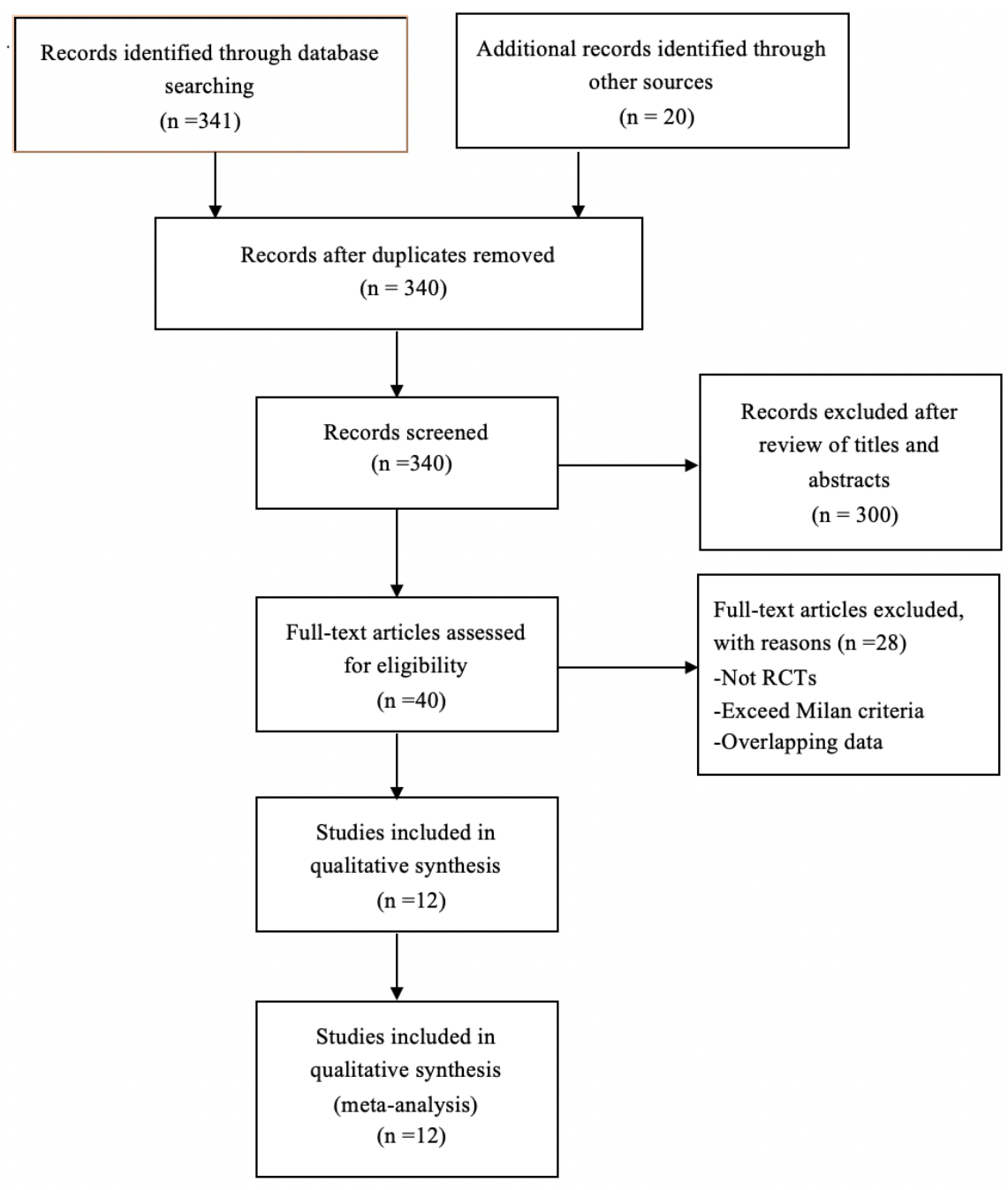

Figure 1

Identification of studies for inclusion. 


\begin{tabular}{|c|c|c|c|c|c|c|c|c|c|c|c|}
\hline 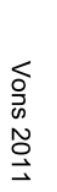 & 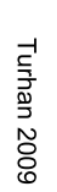 & 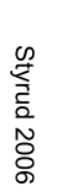 & 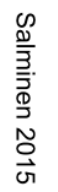 & 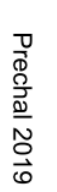 & 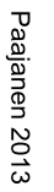 & 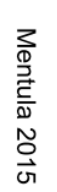 & 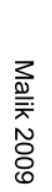 & 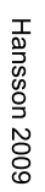 & 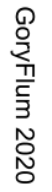 & 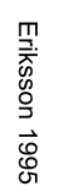 & 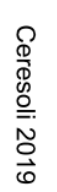 \\
\hline+ & & + & + & (1) & + & $\nu$ & & & + & $\nu$ & + \\
\hline+ & & + & + & $\nu$ & + & $\nu$ & & & + & $\nu$ & + \\
\hline$\nu$ & $v$ & $v$ & $\nu$ & + & $\nu$ & & $\nu$ & $\sim$ & + & $v$ & $v$ \\
\hline$v$ & $v$ & $v$ & $\nu$ & + & + & (1) & $\nu$ & $\nu$ & + & $\nu$ & $v$ \\
\hline+ & + & $\nu$ & + & + & + & + & + & & $\nu$ & + & \\
\hline+ & & 1 & + & + & + & + & + & & $\nu$ & & + \\
\hline$\nu$ & & $\nu$ & + & $\nu$ & $\nu$ & + & + & $\nu$ & $\nu$ & + & $\nu$ \\
\hline
\end{tabular}

Random sequence generation (selection bias)

Allocation concealment (selection bias)

Blinding of participants and personnel (performance bias)

Blinding of outcome assessment (detection bias)

Incomplete outcome data (attrition bias)

Selective reporting (reporting bias)

Other bias

Low risk of bias
Random sequence generation (selection bias)

Allocation concealment (selection bias)

Blinding of participants and personnel (performance bias)

Blinding of outcome assessment (detection bias)

Incomplete outcome data (attrition bias)

Selective reporting (reporting bias)

Other bias

B

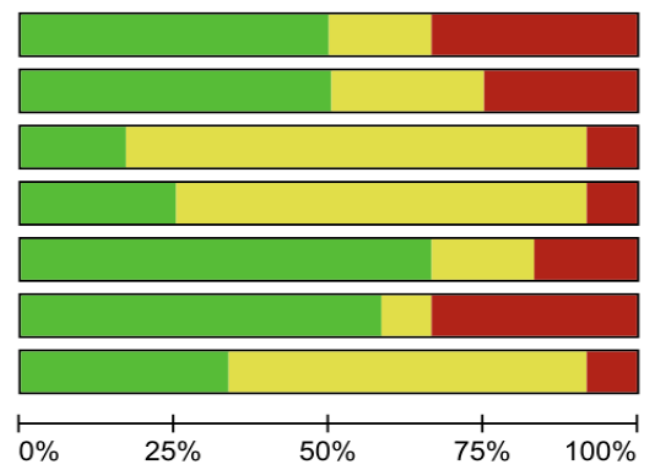

High risk of bias

\section{Figure 2}

Risks of bias summary $(A)$ and risk of bias graph $(B)$ in the randomized controlled trials included in the meta-analysis. All trials were classified as trials with a high risk of bias. 


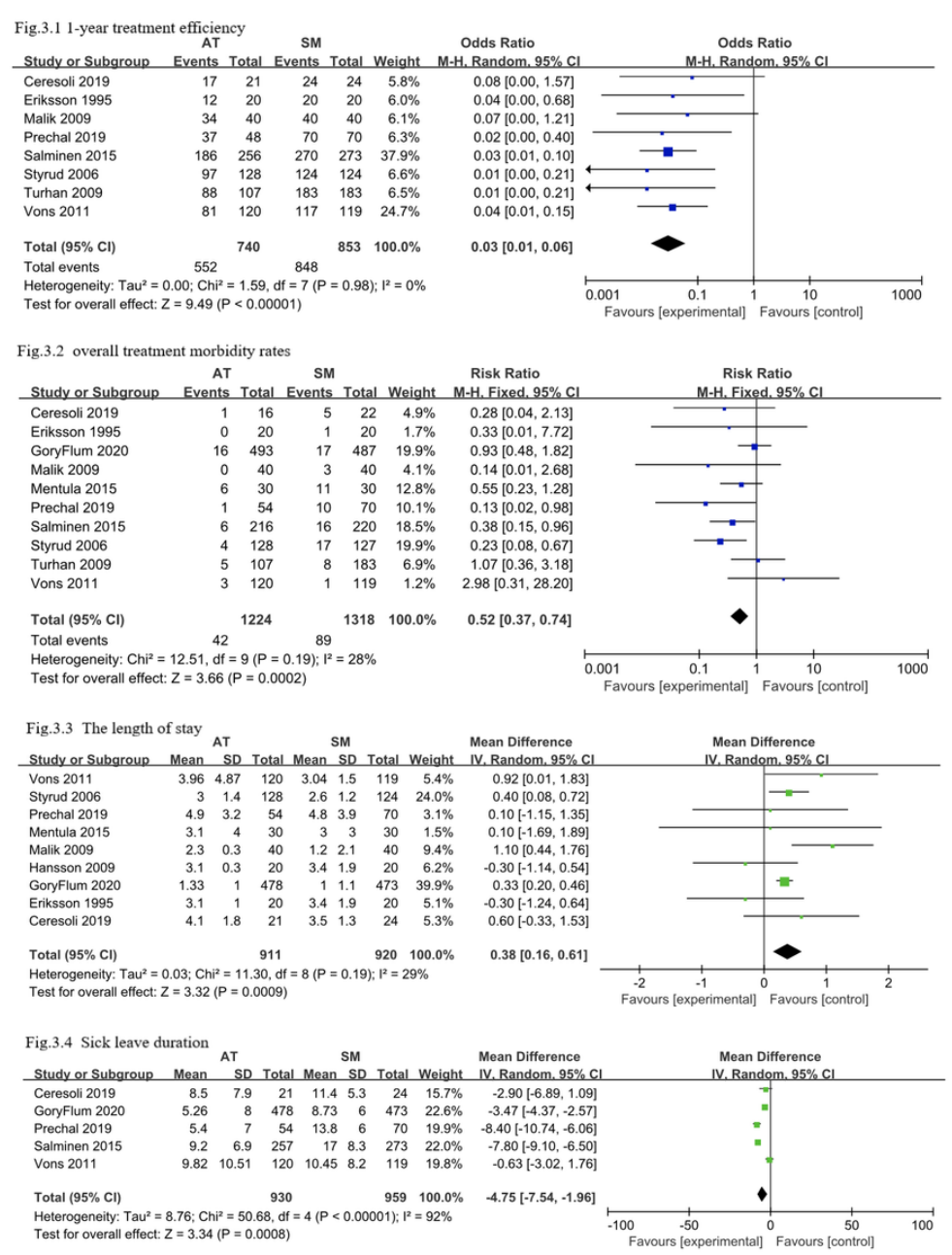

\section{Figure 3}

3.1: Treatment efficacy of 1 year analysis comparing patients in the antibiotics group to those in the appendectomy group.

3.2: Morbidities rate by antibiotics vs. appendectomy for the treatment of AA.

3.3: Length of hospital stay by antibiotics vs. appendectomy for the treatment of AA.

3.4: Forest plot for analysis of Sick leave duration 
AT

SM

Risk Ratio

Risk Ratio

Study or Subgroup Events Total Events Total Weight M-H, Random, $95 \% \mathrm{Cl}$

2.2.1 uncomplicated population

Ceresoli 2019

116

$5 \quad 22 \quad 6.5 \%$

Prechal 2019

154

Salminen 2015

$6 \quad 216$

Styrud 2006

$4 \quad 128$

Vons 2011

Subtotal $(95 \% \mathrm{Cl})$

3120

Total events 15

$\begin{array}{rrr}10 & 70 & 6.6 \% \\ 16 & 220 & 13.9 \% \\ 17 & 127 & 12.7 \% \\ 1 & 119 & 5.7 \% \\ & \mathbf{5 5 8} & \mathbf{4 5 . 4 \%}\end{array}$
49

Heterogeneity: $\mathrm{Tau}^{2}=0.14 ; \mathrm{Chi}^{2}=5.03, \mathrm{df}=4(\mathrm{P}=0.28) ; \mathrm{I}^{2}=20 \%$

Test for overall effect: $Z=2.94(P=0.003)$

2.2.2 unselected population

$\begin{array}{lrrrrr}\text { Eriksson 1995 } & 0 & 20 & 1 & 20 & 3.4 \% \\ \text { GoryFlum 2020 } & 18 & 493 & 17 & 487 & 16.1 \% \\ \text { Hansson 2009 } & 36 & 119 & 79 & 250 & 18.4 \% \\ \text { Malik 2009 } & 0 & 40 & 33 & 40 & 4.2 \% \\ \text { Turhan 2009 } & 5 & 107 & 8 & 183 & 12.4 \% \\ \text { Subtotal (95\% Cl) } & & 779 & & 980 & \mathbf{5 4 . 6 \%} \\ \text { Total events } & 59 & & 138 & & \end{array}$

Heterogeneity: $\mathrm{Tau}^{2}=0.48 ; \mathrm{Chi}^{2}=14.12, \mathrm{df}=4(\mathrm{P}=0.007) ; \mathrm{I}^{2}=72 \%$

Test for overall effect: $Z=0.84(P=0.40)$

Total $(95 \% \mathrm{Cl})$

1313

Total events 74

$1538 \quad 100.0 \%$

Heterogeneity: $\mathrm{Tau}^{2}=0.55 ; \mathrm{Chi}^{2}=28.88, \mathrm{df}=9(\mathrm{P}=0.0007) ; \mathrm{I}^{2}=69 \%$

Test for overall effect: $Z=2.08(P=0.04)$

Test for subgroup differences: $\mathrm{Chi}^{2}=1.70, \mathrm{df}=1(\mathrm{P}=0.19), \mathrm{I}^{2}=41.0 \%$
$0.28[0.04,2.13]$

$0.13[0.02,0.98]$

$0.38[0.15,0.96]$

$0.23[0.08,0.67]$

$2.98[0.31,28.20]$

$0.34[0.16,0.70]$

M-H. Random. 95\% C

$0.33[0.01,7.72]$

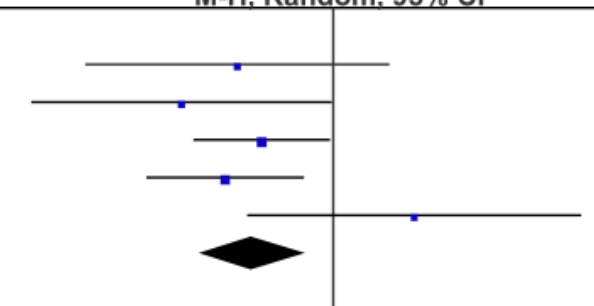

$1.05[0.55,2.01]$

$0.96[0.69,1.33]$

$0.01[0.00,0.24]$

$1.07[0.36,3.18]$

$0.70[0.31,1.60]$

$\leftarrow$

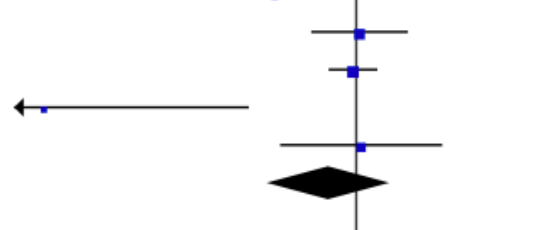

$0.51[0.27,0.96]$

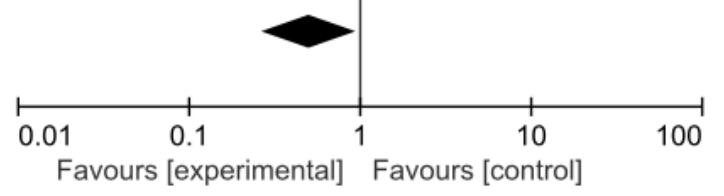

Figure 4

Morbidities rate subgroup analysis comparing uncomplicated population and unselected patients. 


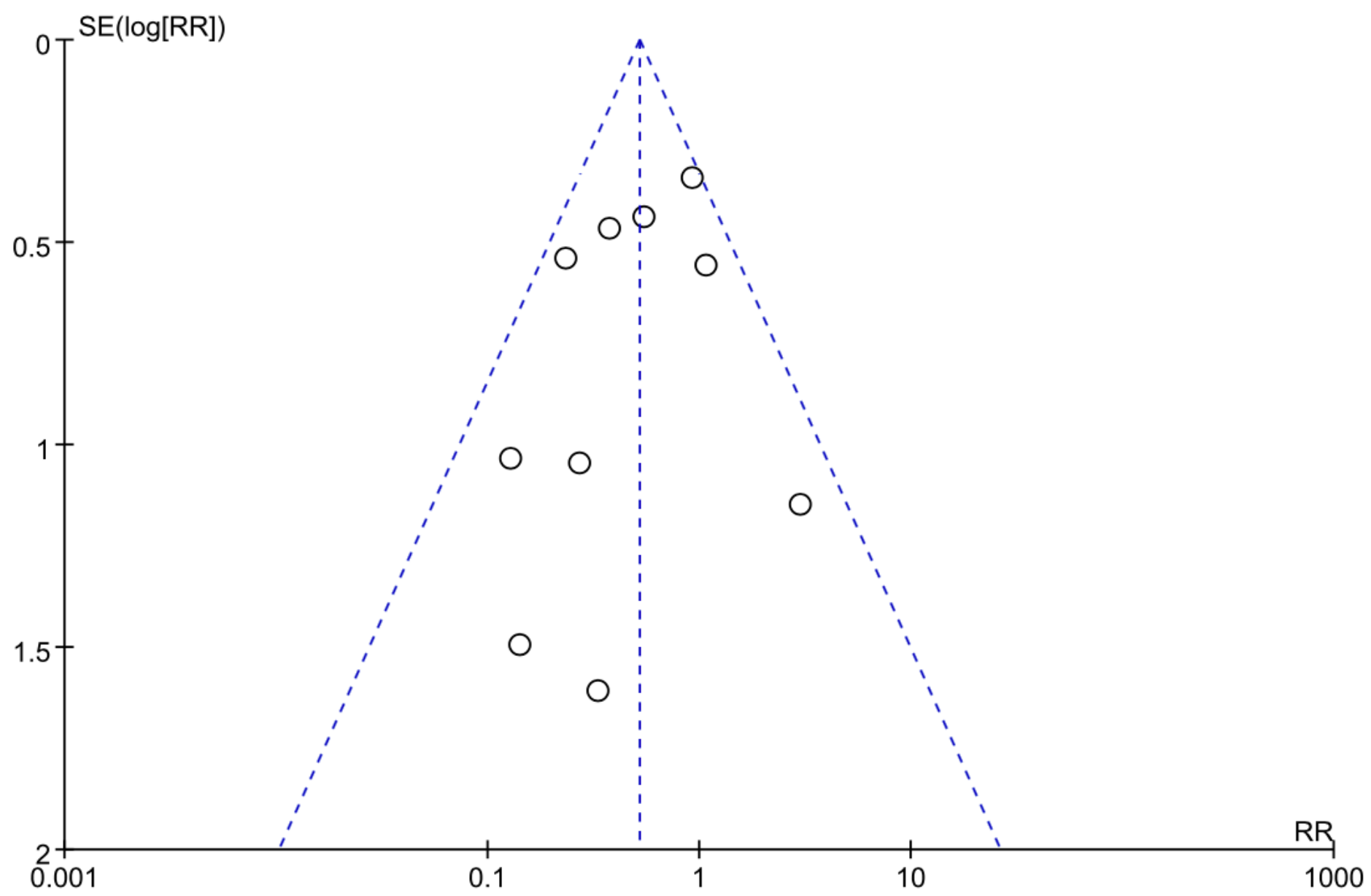

Figure 5

Funnel plot of comparison of morbidities rate in the antibiotics group to those in the appendectomy group. 